\title{
JUSTYNA OWLASIUK
}

\section{ZNACZENIE HISTORII MÓWIONEJ \\ JAKO METODY BADAWCZEJ NA PRZYKLADZIE \\ BIALORUSKIEJ SPOLECZNOŚCI WIEJSKIEJ \\ POGRANICZA POLSKO-BIALORUSKIEGO}

\section{DOI: $10.15290 /$ sp.2016.24.12}

Słowa kluczowe: historia mówiona, białoruska społeczność wiejska, pogranicze polsko-białoruskie, II wojna światowa, okupacja niemiecka

Historia mówiona rozwinęła się w Stanach Zjednoczonych po zakończeniu II wojny światowej, kiedy to rozpoczęto prace nad spisywaniem biografii przedstawicieli amerykańskich elit ${ }^{1}$. Na kontynent europejski ta metoda badawcza dotarła pod koniec lat $60 .{ }^{2} \mathrm{~W}$ przeciwieństwie do Stanów Zjednoczonych, w Europie przedmiotem zainteresowań badaczy stali się członkowie niższych klas społecznych. Określano ich mianem wykluczonych, nieposiadających prawa głosu, a co za tym idzie pozbawionych możliwości kształtowania własnych dziejów ${ }^{3}$. Oral history zaczęła być tym samym wykorzystywana przez historię społeczną, gdyż wypełniała lukę, dostarczając informacji na temat przeszłości najniższych warstw ludności.

Od momentu powstania stosunek środowisk naukowych wobec historii mówionej uległ silnej ewolucji. Początkowo zwolennicy oral history stawiali relacje na równi z innymi źródłami historycznymi i opowiadali się za posługiwaniem się nimi jako rzetelnymi informacjami o wydarzeniach z przeszłości. Biorąc jednak pod uwagę zindywidualizowaną chronologię historii mówionej, odstąpiono od stanowiska wykorzystywania wywiadów w procesie tworzenia faktów historycznych. Głównym zadaniem źródeł ustnych stało

1 Pomysł narodził się jeszcze w latach 30. XX w., jednak ze względu na problemy finansowe pierwszy wywiad został przeprowadzony w $1948 \mathrm{r}$.

2 T. Królik, Wprowadzenie do oral history, http://homepage.univie.ac.at/philipp.ther/breslau /html/wprowadzenie.html [04.08.2016].

3 Tamże. 
się natomiast przedstawienie, jak minione wydarzenia zostały zapamiętane przez ich uczestników ${ }^{4}$. Współcześnie zatem, historia mówiona jako metoda badawcza rozumiana jest jako zgromadzenie i dokonanie krytycznej analizy wywiadów udzielonych przez świadków wydarzeń historycznych. Według dokładniejszej definicji oral history to „samoświadoma, poddana pewnej dyscyplinie rozmowa między dwoma ludźmi na temat niektórych aspektów (doświadczonej) przeszłości uważanych za historycznie istotne, prowadzona z zamiarem jej zarejestrowania" ${ }^{5}$, mająca na celu uzyskanie odpowiedzi na pytanie nie "Jak było?", a "Jak wydaje się, że było?".

W Polsce, podobnie jak na Zachodzie, źródła wywołane cieszą się coraz większą popularnością ${ }^{6}$. Oral history, stając się metodą interdyscyplinarną, jest wykorzystywana przez środowiska historyków, socjologów, psychologów, antropologów, a także literaturoznawców ${ }^{7}$. Na atrakcyjność historii mówionej niewątpliwie wpływa specyfika źródła badawczego, jakim są relacje. Zwolennicy tej metody zwracają uwagę na aspekty, które wyróżniają wywiady na tle klasycznych źródeł historycznych. Za główny walor oral history uznaje się bezpośredni kontakt z relacjonującym, „dzięki czemu przeszłość staje się bliższa i bardziej zrozumiała" ${ }^{8}$. Osoba przeprowadzająca wywiad ma możliwość uszczegóławiania kwestii kluczowych z perspektywy prowadzonego badania, czy też poddawania kontroli przytaczanych treści jeszcze w trakcie trwania wywiadu. Umiejętnie kierowana rozmowa skutkuje otwarciem się badanego i powrotem do wspomnień o niekiedy bardzo ważnej wartości badawczej. Fakt osobistej relacji badacza z narratorem pozwala na odczytywanie gestów towarzyszących wypowiedzi rozmówcy, co również bywa nośnikiem informacji i powinno zostać wykorzystane przy analizie wywiadu. Bezpośredni kontakt z relacjonującym czyni, ponadto, z wywiadów stosunkowo łatwo osiągalne źródło, dostępne dla szerszego grona odbiorców niż zgromadzone $\mathrm{w}$ archiwach dokumenty ${ }^{9}$.

4 M. Kurkowska-Budzan, Historia zwyktych ludzi. Wspótczesna angielska historiografia dziejów społecznych, Kraków 2003, s. 181-183.

5 P. Filipkowski, Historia mówiona i wojna, http://biblioteka.teatrnn.pl/dlibra/Content/9618/ Historia_mowiona_i_wojna.pdf [04.08.2016].

6 W Polsce oraz w pozostałych krajach Europy Środkowo-Wschodniej intensyfikacja prac nad historią mówioną nastąpiła po upadku systemu komunistycznego.

7 I. Lewandowska, Historycy wobec metody oral history. Przeglad polskiej literatury naukowej, [w:] Historia. Archiwistyka. Praca naukowa. Prace dedykowane Profesorowi Bohdanowi Ryszewskiemu, red. M. Świgoń, Olsztyn 2009, s. 127.

8 I. Lewandowska, Oral history we wspótczesnej Polsce - badania, projekty, stowarzyszenia, „Wrocławski Rocznik Historii Mówionej" 2011, t. 1, s. 91.

9 D. Kałwa, Historia mówiona w krajach postkomunistycznych. Rekonesans, „Kultura i Historia” 2010, nr 18, http://www.kulturaihistoria.umcs.lublin.pl/archives/1887 [04.08.2016]. 
Prekursorka polskiego nurtu historii mówionej - Krystyna Kersten - wyodrębniła trzy zalety relacji ustnych opowiadające się za wykorzystywaniem wywiadów w pracach badawczych. Jako pierwszy czynnik wymieniła posługiwanie się relacjami w celu weryfikacji rzetelności źródeł pisanych. Po drugie, podkreśliła przydatność wywiadów w przypadku uzupełniania opisu przebiegu wydarzeń nieposiadających wystarczającej liczby dokumentów archiwalnych. Natomiast za trzeci walor relacji uznała pomoc w określaniu motywów, którymi kierowali się aktorzy minionych wydarzeń. Ponadto, K. Kersten zwróciła uwagę na możliwość wykorzystania źródeł ustnych w odtwarzaniu klimatu konkretnych zdarzeń historycznych ${ }^{10}$. Bez wątpienia podstawową zaletą oral history jest uzupełnianie, a nawet opisanie dziejów, które nie zostawiły po sobie dokumentów archiwalnych bądź ukazały przeszłość w sposób jednostronny ${ }^{11}$. Wywiady jako źródło stwarzają bowiem możliwość odkrycia i uwiecznienia nieoficjalnego zasobu wiedzy, historii „zwykłych ludzi" oraz społeczności mniejszościowych i nieuprzywilejowanych ${ }^{12}$.

Badania oral history prowadzone $\mathrm{w}$ obrębie danej społeczności, jak np. białoruska ludność pogranicza polsko-białoruskiego, dają ogląd pamięci wykreowanej w ramach tej grupy. Przytaczane w relacjach wspomnienia ukazują sposób zapamiętania konkretnych postaci czy wydarzeń historycznych wynikający z przynależności do tej, a nie innej zbiorowości, będącej wypadkową różnych doświadczeń. Pomocą w ukazaniu pamięci grupy służyć miały służyć badania przeprowadzone wśród Białorusinów zamieszkujących obszary wiejskie obecnego pogranicza polsko-białoruskiego. Zgromadzonych zostało piętnaście relacji, z czego siedmiu udzielili przedstawiciele mniejszości białoruskiej w Polsce (powiat hajnowski - grupa polska) i ośmiu Białorusini będący obywatelami Republiki Białoruś (rejon kamieniecki - grupa białoruska). Przy doborze badanych kierowano się wiekiem relacjonujących (możliwość przywołania interesujących badacza wydarzeń) oraz reprezentowaniem przez narratorów tej samej narodowości (białoruska) i wyznania (prawosławne). Tematyka wywiadów skupiała się wokół sowieckich i niemieckich rządów podczas II wojny światowej, dlatego też przy przeprowadzaniu relacji ograniczono się do przedstawicieli białoruskiej społeczności wiejskiej pogranicza polsko-białoruskiego urodzonych przed 1939 r., pamiętających

10 K. Kersten, Relacje jako typ źródła historycznego, [w:] Pamiętnik X Powszechnego Zjazdu Historyków Polskich w Lublinie, 17-21 września 1968 r. Referaty plenarne. Sekcje VII-XI, Warszawa 1968, s. 324.

11 I. Lewandowska, Historycy wobec metody..., s. 133.

12 D. Kałwa, dz. cyt. 
wojnę. Celem prowadzonych badań była próba przedstawienia pamięci białoruskiej społeczności wiejskiej związanej z wydarzeniami lat 1939-194413, tym samym zaś odpowiedzenie na pytanie jakie zagadnienia przedstawiciele tej grupy łączą z okresem II wojny światowej oraz w jaki sposób i dlaczego właśnie tak to zostało zapamiętane. Ponadto, zamierzano sprawdzić, czy istnieją różnice $\mathrm{w}$ zapisaniu się tych samych wydarzeń w świadomości Białorusinów z Polski i Białorusi.

Obrany cel prowadzonych badań czyni z relacji ustnych wartościowe źródło, zaś z historii mówionej metodę pozwalającą na uzyskanie odpowiedzi na postawione pytania. Atrakcyjność wywiadów i samej oral history w podjętej tematyce polegała także na braku alternatywnych źródeł. Niemniej istotną kwestią przemawiającą za wykorzystaniem relacji była również możliwość zbudowania historii "od dołu” i skonfrontowania jej z tzw. wiedzą podręcznikową. Ze względu na szeroki zakres tematyczny, jako przykład możliwości i efektów jakie daje posłużenie się w badaniach metodą historii mówionej, poniżej omówione zostaną jedynie lata 1941-1944. Skupienie się na okupacji niemieckiej podyktowane jest rolą jaką ten okres pełnił w przeprowadzonych wywiadach. Po pierwsze, członkowie badanej grupy, będąc w czasie II wojny światowej dziećmi, lepiej pamiętają późniejszy niż okupacja sowiecka okres władzy nazistowskiej. Z drugiej zaś strony, wkroczenie wojsk niemieckich w 1941 r. stało się dla białoruskiej społeczności wiejskiej wydarzeniem, któremu towarzyszyły silne emocje. Oznaczało bowiem zetknięcie się z nieznaną kulturą i obcymi żołnierzami. Ten problem nie wystąpił we wrześniu 1939 r., kiedy wschodnie ziemie międzywojennej Polski zostały zajęte przez Armię Czerwoną. Członkowie wojsk sowieckich reprezentowali znaną ludności białoruskiej wschodnią kulturę, bariery nie stanowił także język Czerwonoarmistów. Obcość i strach przed Niemcami, spotęgowane zarysowanym kontrastem między przedstawicielami obu wojsk, stały się przyczyną, dla której lata władzy nazistowskiej wzbudzały silniejsze emocje i zajęły więcej miejsca w przytaczanych przez członków badanej grupy wspomnieniach.

Jak już zauważono, pamięć danej zbiorowości kreują doświadczenia, zarówno te związane bezpośrednio z przywoływanym wspomnieniem, jak i późniejsze. Dlatego też podejmując próbę opisania okupacji niemieckiej

13 Latem 1944 r. doszło do ponownego wkroczenia Armii Czerwonej na północno-wschodnie ziemie II RP i zakończenia działań zbrojnych na tym obszarze. Wycofanie się Wehrmachtu i wyzwolenie spod władzy nazistowskiej członkowie badanej grupy określali jako koniec II wojny światowej. 
widzianej oczami białoruskiej ludności wiejskiej należy wziąć pod uwagę elementy, które mogły znacząco rzutować na obraz przeszłości. Bez wątpienia, obok indywidualnych, dobrych bądź złych przeżyć związanych z latami władzy nazistowskiej, na pamięć badanych o okupacji wpłynęły również czynniki zewnętrzne, którym poddawani byli relacjonujący w ciągu swojego życia - od ponownego wkroczenia Armii Czerwonej do przeprowadzenia wywiadu. Wskazać tu należy przede wszystkim szeroko rozumianą państwową politykę historyczną oraz inne powojenne doświadczenia narratorów mogące determinować ich ogląd minionych wydarzeń, na co też zwrócono szczególną uwagę przy analizie zgromadzonych wywiadów.

Zebrane relacje wykazały, iż agresja niemiecka na Związek Sowiecki stała się dla narratorów początkiem prawdziwej wojny, a nawet uznana została przez część z nich za początek właściwej wojny. Powiązanie ataku III Rzeszy z wybuchem II wojny światowej przez niektórych relacjonujących z Białorusi niewątpliwie było skutkiem komunistycznej, a następnie kontynuowanej przez Aleksandra Łukaszenkę, polityki gloryfikacji obrony sowieckiej ojczyzny przed nazistowskim wrogiem ${ }^{14}$. Według oficjalnej komunistycznej propagandy, wkroczenie Armii Czerwonej w 1939 r. na wschodnie rubieże międzywojennej Polski miało na celu wyłącznie niesienie pomocy Białorusinom, Ukraińcom, a także polskim chłopom i robotnikom ${ }^{15}$ i oznaczało zjednoczenie ziem białoruskich. Skoro zajęcie wschodnich rubieży II RP przez wojska sowieckie stało się wyzwoleniem, wojna dla narodu sowieckiego rozpoczęła się $\mathrm{w}$ momencie zachwiania budowy wspólnej sowieckiej ojczyzny atakiem III Rzeszy na ZSRS. Wszechobecny kult walk z lat 1941-1944, nazwanych Wielką Wojną Ojczyźnianą, utrwalany edukacją w szkołach czy obchodzeniem kolejnych rocznic 9 maja, zacierał pamięć o 1 września 1939 r. Aleksander Łukaszenko wykorzystał i rozwinął, silnie gloryfikowaną już w czasach sowieckich, pamięć o wojnie niemiecko-sowieckiej, która także współcześnie stała się istotnym elementem w polityce historycznej państwa białoruskiego. Pomniki, monumenty z nią związane czy weterani wojenni otaczani są na Białorusi swoistą czcią. Między innymi Twierdza Brześć, symbolizująca heroiczną walkę narodu sowieckiego w 1941 r., zajmuje ważną pozycję w białoruskich przewodnikach i jest tłumie

\footnotetext{
14 W. Śleszyński, Kresy Wschodnie czyli Białoruś Zachodnia. Historia, współczesność, pamięć, Łomianki 2013, s. 111-113.

15 D. Boćkowski, Na zawsze razem. Białostocczyzna $i$ Łomżyńskie $w$ polityce radzieckiej $w$ czasie II wojny światowej (IX 1939-VIII 1944), Warszawa 2005, s. 30-32.
} 
odwiedzana przez gości ${ }^{16}$. Pamięć o Wielkiej Wojnie Ojczyźnianej jest ponadto silnie utrwalana $\mathrm{w}$ społeczeństwie poprzez edukację młodzieży oraz białoruskie media (prasa, radio, film).

Przypadki łączenia wkroczenia Wehrmachtu z początkiem wojny występowały także $\mathrm{w}$ relacjach narratorów $\mathrm{z}$ Polski, miały jednak inny charakter. Relacjonujący $\mathrm{z}$ grupy polskiej utożsamiali wojnę z przetaczającym się frontem, dlatego też nie postrzegali wydarzeń z września 1939 r. w kategorii konfliktu zbrojnego. Choć zdawano sobie sprawę, iż „jakaś” wojna trwa, nie miało to bezpośredniego przełożenia na życie na wsi. W pamięci przedstawicieli białoruskiej społeczności wiejskiej walki nie toczyły się pomiędzy 1 września 1939 a 8/9 maja 1945 r. Wojna była wtedy, gdy w okolicach przez nich zamieszkiwanych trwały boje, natomiast pozostały okres to czas funkcjonowania sowieckiego bądź nazistowskiego prawa. Jako że relacjonujący wspominali, iż jesienią 1939 r. nie toczyły się żadne boje, dla badanej grupy pierwszy konflikt zbrojny realnie rozpoczął się 22 czerwca 1941 r., kiedy to zamieszkiwane przez nich wsie stawały się miejscem starć niemiecko-sowieckich. Jeśli nawet front nie przechodził przez dane miejscowości, działania zbrojne dotykały sąsiednie tereny. Spośród członków badanej grupy z Polski, świadkami największych niemiecko-sowieckich walk stali się narratorzy zamieszkujący miejscowość Stare Berezowo. Wojska nazistowskie zaskoczone atakiem ukrywających się nieopodal wsi Czerwonoarmistów, odpowiedzialnością obarczyły mieszkańców Starego Berezowa, czego skutkiem było podpalenie zabudowań. Z pożaru ocalało tylko kilka domów ${ }^{17}$.

Niemeć pryszoł do seła i howoryt: „Czy ne ma tut Ruskich?”. Lude ż każut, że ne ma. Bo ne było. A wony [Czerwonoarmiści - J.O.] za wagonami sidieli. A nichto ne znał. Tody szto, Niemeć beretsia i wyhaniaje wsiech za seło, aż pud Szostakowo. (...) Za toje, szto lude (...) skazali, że [nie ma żołnierzy sowieckich - J.O.]. (...) Zaszli do Szostakowa do swoich, aż posla baczymo, za kłuniu wyjszli, horyt Berezowo nasze. I para chatoł ostałosia u Berezowi. Kilka chatoł ostałosia, resztu wsio spalili, wsio spalili ${ }^{18}$.

U nas dwoje koni, żerebja zhoreło. Korowy to ja odczynił chlieu, to korowy utekli. Stojali na dwore, to jak horeło utekli. A owieczki pohoreli ${ }^{19}$.

16 W. Śleszyński, dz. cyt., s. 100.

17 Relacja Anny Owłasiuk (Stare Berezowo) z 11 XI 2012 (zbiory autorki); Relacja Józefa Moroza (Stare Berezowo) z 26 VIII 2014 (zbiory autorki); Relacja Mikołaja Owłasiuka (Stare Berezowo) z 4 VII 2012 (zbiory autorki); Relacja Niny Moroz (Stare Berezowo) z 7 VI 2012 (zbiory autorki).

18 Relacja Mikołaja Owłasiuka (Stare Berezowo) z 4 VII 2012...

19 Relacja Józefa Moroza (Stare Berezowo) z 26 VIII 2014... 
Mieszkańcy wspomnianej wisi nie byli jedynymi, którzy ucierpieli w czerwcu 1941 r. Skala zniszczeń pozwala stwierdzić, iż agresja III Rzeszy została określona przez grupę polską pierwszą wojną nie tylko z racji toczonych walk, ale również ze względu na skutki, które wywołały działania zbrojne. W wyniku niemiecko-sowieckich starć ginęła miejscowa ludność, w płomieniach społeczność wiejska traciła domy, zabudowania gospodarskie, a także zamknięte w oborach zwierzęta i przechowywane w spichlerzach zapasy.

Do zakorzenienia się w pamięci narratorów z Polski ataku III Rzeszy na ZSRS jako początku wojny przyczynić się mógł również stosunek badanych do żołnierzy Armii Czerwonej i Wehrmachtu. W zgromadzonych wywiadach wyraźnie zarysowane zostało utożsamianie się relacjonujących z przedstawicielami wojsk sowieckich, wynikłe z powiązań językowych, kulturowych, a także religijnych (według niektórych narratorów samoloty niemieckie w 1941 r. leciały „bombiti naszych”20). Określanie Czerwonoarmistów "swoimi”, stało przede wszystkim w opozycji do „obcych” żołnierzy niemieckich. W związku z tym, w pamięci badanych w 1939 r. wkroczyły "swoje”, zaś w 1941 r. "obce” wojska. Sympatia w stosunku do żołnierzy sowieckich była utrwalana wśród Białorusinów także po wojnie. Z pewnością część społeczności białoruskiej jako mniejszości narodowej i religijnej, której przyszyto łatkę zwolenników władzy sowieckiej, odczuwała silną więź ze wschodnimi sąsiadami, co też mogło przełożyć się na kreowany obraz żołnierzy Armii Czerwonej. Ukształtowana tożsamość przedstawicieli grupy polskiej powodowała, iż agresja nazistowska stawała się ich wojną, gdyż wymierzona została przeciwko „swoim” wojskom. Nie była to wszakże cecha charakterystyczna dla ogółu relacjonujących z Polski. Brak jednoznacznej postawy narratorów ukazuje wielobiegunowość problemu tożsamości białoruskiej społeczności wiejskiej w Polsce.

Przywołane powyżej czynniki determinowały nie tylko silne zapisanie się $\mathrm{w}$ pamięci obu badanych grup samego wybuchu wojny niemiecko-sowieckiej, ale także całego okresu okupacji nazistowskiej. Narratorzy zarówno z Polski, jak i Białorusi, przytaczając wspomnienia związane z wydarzeniami lat 1941-1944, w szczególności duży nacisk kładli na omówienie następujących zagadnień: kontyngenty, wywózki na roboty przymusowe do III Rzeszy oraz działalność partyzantki sowieckiej. Każda z wymienionych kwestii bezpośrednio rzutowała na codzienność relacjonujących. Należy pamiętać, iż członkowie badanej grupy to przedstawiciele społeczności wiejskiej, dla której obok rodziny najważniejszą rzeczą było prowadzone gospodarstwo rolne,

20 Relacja Marii Wasiluk (Rzepiska) z 1 XI 2012 (zbiory autorki). 
zaś rytm dnia wyznaczały adekwatne do pory roku prace gospodarskie. Dlatego też to nie zagadnienia polityczne same w sobie, ale kwestie wpływające na zaburzenie życia codziennego miały dla ludności wiejskiej największe znaczenie, co dość silnie przejawiało się w zgromadzonych wywiadach.

Już na początku 1941 r. strona niemiecka wypracowała założenia dotyczące wykorzystania surowcowego, przemysłowego, a także eksploatację siły roboczej terenów wchodzących w skład ZSRS21. Mniejszymi obciążeniami w stosunku do ziem białoruskich znajdujących się pod zarządem wojskowym, obarczony został m.in. okręg białostocki ${ }^{22}$, w granicach którego znalazły się zamieszkiwane przez badanych obszary. Pomimo „ulgowego" traktowania $\mathrm{w}$ stosunku do reszty okupowanych terenów (z czego większość narratorów mogła nie zdawać sobie sprawy także w momencie przeprowadzania wywiadu), kwestia obowiązkowych dostaw wzbudzała w badanych duże emocje. Wprawdzie relacjonujący, co warte podkreślenia, i z Polski i z Białorusi zwracali uwagę na uwzględnianie przez stronę niemiecką przy wyznaczaniu wielkości dostaw rozmiarów danego gospodarstwa czy liczbę dzieci ${ }^{23}$, to jednak w kontyngentach widziano, co zrozumiałe, przede wszystkim uszczuplanie własnych zapasów.

U nas każdy hod nada było kabana zdat', potomu szto u bat'ka naszeho pola było mniho. A u koho mencz to za dwa hoda raz kabana (...) Nichto nic ne kazał, ni słowa. Sami wodu jeli, a mołoko nesut ${ }^{24}$.

Była wprost bida, nu bo ne było można ani swiniata zakołoti, ani nic ne dawali, treba było wsio odwezti. Prychodili wony, ostatnie ne zabirali, ne każu (...) jak pryszoł do szpichera i zobaczył, że tam szcze zboża dużowato je, nu to skazał sioje odwezti, a toje szcze pokinuti, u koho dieti byli ${ }^{25}$.

Za brakiem akceptacji panującej nazistowskiej zasady „W pierwu oczered” daj mnie, a potom budie tiebie" 26 , przemawiają wspomnienia związane z zakopywaniem części produktów spożywczych, ukrywaniem zwierząt, czy też

21 E. Mironowicz, Zmiany struktury etnicznej na Białorusi w okresie okupacji niemieckiej (1941-1944), „Białoruskie Zeszyty Historyczne” 2004, nr 21, s. 105.

E. Mironowicz, Białorusini w Polsce 1944-1949, Warszawa 1993, s. 99.

23 Relacja Andrzeja Zawackiego (Koryciski) z 31 III 2013 (zbiory autorki); Relacja Niny Dračuk (Rożkówka) z 12 X 2013 (zbiory autorki); Relacja Mikołaja Owłasiuka (Stare Berezowo) z 4 VII 2012...; E. Mironowicz, Prowincja i stolica - okupacyjna codzienność na Biatorusi, „Białoruskie Zeszyty Historyczne" 2013, nr 40, s. 194.

24 Relacja Niny Dračuk...

25 Relacja Andrzeja Zawackiego (Koryciski) z 31 III 2013...

26 Relacja Gerasima Dračuka (Rożkówka) z 11 I 2014 (zbiory autorki). 
składaniem fałszywych deklaracji. Także nakładane przez okupanta obostrzenia, jak wprowadzenie zakazu domowego mielenia mąki27, w konfrontacji z ludzką determinacją i pomysłowością nie były w stanie w pełni przeciwdziałać uchylaniu się chłopów od przekazywania kontyngentów. Przykładowo, nielegalnego uboju świń dokonywano nocą w chlewach, stodołach, a nawet $\mathrm{w}$ domach mieszkalnych, mięso natomiast zakopywano $\mathrm{w}$ ziemi. Znacznie skuteczniejszą metodą wymuszającą sankcjonowanie prawa okupacyjnego okazało się objęcie represjami osób unikających wypełniania obowiązku dostawczego. Zgodnie z płynącymi z Berlina instrukcjami, każdy przejaw utrudniania realizacji nazistowskich planów, w tym przypadku eksploatacji gospodarczej zajętych obszarów, miał być surowo karany ${ }^{28}$. Nazistowskie kary badani opisywali jako „znikanie” miejscowych, którzy zostali przyłapani bądź byli jedynie podejrzani o nielojalne zachowanie.

Prócz kwestii czysto praktycznych polegających na uszczuplaniu zapasów, uchylanie się wobec nakładanych zobowiązań mogło mieć również podłoże emocjonalne. Wśród białoruskiej społeczności wiejskiej panowała niechęć i strach przed okupantem niemieckim (w przeciwieństwie do Czerwonoarmistów), co znajduje odzwierciedlenie w zebranych relacjach ${ }^{29}$. Nieznajomość kultury, religii, tradycji i przede wszystkim języka przedstawicieli Wehrmachtu, w oczach badanych czyniło ich dla ludności białoruskiej "obcymi”. Powojenne napiętnowanie nazistowskich działań na okupowanych terenach przez zwycięskie państwa, aktualne także współcześnie, tylko wzmocniło negatywną pamięć o nakładanych kontyngentach. Naturalnym wydaje się fakt, iż w przywoływanych wspomnieniach dąży się do jak najlepszego ukazania własnej osoby, w co też wpisują się relacje mówiące o obciążeniu ludności chłopskiej i niechętnym wypełnianiu okupacyjnego prawa. Nie podważając znaczenia negatywnego wpływu obowiązkowych dostaw na poziom życia mieszkańców wsi, ogólna powojenna krytyka wobec nazistowskich rozwiązań dodatkowo utrwalała wykreowany przez relacjonujących już w czasie wojny obraz. W przypadku grupy białoruskiej również wspominania wcześniej państwowa polityka historyczna (w wydaniu komunistycznym i łukaszenkowskim) znajdowała odbicie $\mathrm{w}$ przytaczanych wywiadach. $\mathrm{W}$ obrazie walki z nazistowskim najeźdźcą nie mogło być miejsca na jakiekolwiek zro-

27 Relacja Marii Wasiluk (Rzepiska) z 17 IX 2013 (zbiory autorki).

28 E. Mironowicz, Rok 1941 na Białorusi, „Białoruskie Zeszyty Historyczne” 2011, nr 35, s. 107.

29 Relacja Andrzeja Zawackiego (Koryciski) z 31 III 2013...; Relacja Józefa Moroza (Stare Berezowo) z 7 VI 2012 (zbiory autorki); Relacja Mihaila Mel'ničuka (Podbielskie Ogrodniki) z 12 X 2013 (zbiory autorki). 
zumienie okupowanej ludności dla, w tym przypadku, nakładanych kontyngentów. „Pozytywne” wypowiedzi narratorów o Niemcach podsumowywano zdaniem w stylu

My hołodnyje nie byli. No Niemcy preslieduwali (...), razstreluwali. U etom smyslie było chuże $\mathrm{e}^{30}$.

Kolejnym zagadnieniem zajmującym ważną pozycję we wspomnieniach dotyczących okupacji niemieckiej było wysyłanie młodzieży do pracy na terenie Niemiec. Wraz z końcem $1941 \mathrm{r}$. władze nazistowskie rozpoczęły działania zachęcające roczniki 1920-1923 do wyjazdu na zachód. Prowadzona akcja propagandowa nie przyniosła jednak oczekiwanych rezultatów, w związku z czym rozpoczęto przymusową deportację ludności ${ }^{31}$, określanej przez narratorów jako „biezpłatnyje raboczyje” 32 . Istotna rola jaką w przeprowadzonych wywiadach pełniło zagadnienie wywózek na roboty przymusowe do III Rzeszy podyktowana była kilkoma przyczynami. Po pierwsze, wyjazd oznaczał de facto rozerwanie więzi rodzinnych i zmniejszenie rąk do pracy we własnych gospodarstwach, co niewątpliwie naruszało codzienność miejscowych. $Z$ drugiej zaś strony, szerokie omówienie przez badanych tego tematu wynikało $z$ faktu, iż na roboty wysłano mieszkających po sąsiedzku starszych kolegów narratorów. Uzmysławiało to, iż w dłuższej perspektywie także sami relacjonujący mogą znaleźć się na liście osób skierowanych do III Rzeszy.

Przymusowe roboty $\mathrm{w}$ Niemczech zapisały się $\mathrm{w}$ pamięci relacjonujących wyłącznie w kategorii traumy i kary, o czym świadczą liczne wspomnienia o podejmowaniu prób ich uniknięcia. Miały miejsce incydenty fałszowania świadectw urodzeń i chrztów ${ }^{33}$ czy wystawiania przyszłym robotnikom przez znajomych lekarzy negatywnej opinii zdrowotnej ${ }^{34}$. Zdarzały się także przypadki nie stawiania się młodzieży po upływie terminu otrzymanej przepustki celem powrotu do miejsca pracy ${ }^{35}$ oraz ucieczek $\mathrm{w}$ trakcie transportu, a także $\mathrm{z}$ samych robót ${ }^{36}$, które notabene wiązały się ze srogimi karami ze strony okupanta (m.in. osadzenie w obozie karnym w Bielsku

30 Relacja Vadima Sinâka (Kamieniuki) z 25 IX 2013 (zbiory autorki).

31 E. Mironowicz, Zmiany struktury etnicznej na Białorusi..., s. 112.

32 Relacja Vadima Sinâka...

33 E. Mironowicz, Białorusini w Polsce..., s. 99.

34 Relacja Vadima Sinâka...

35 Relacja Marii Wasiluk (Rzepiska) z 1 XI 2012...

36 Relacja Mikołaja Owłasiuka (Stare Berezowo) z 4 VII 2012... 
Podlaskim ${ }^{37}$ ). Skuteczną, ale i ryzykowną metodę stanowiło wstępowanie w szeregi sowieckiego ruchu oporu ${ }^{38}$. Przyznać należy, iż w relacjach białoruskiej grupy przewijały się pozytywne wspomnienia związane z sytuacją, w jakiej znaleźli się niektórzy znajomi i bliscy narratorów. Trafiając do „dobrego" gospodarza, traktowani byli w Niemczech jak członkowie rodziny, niekiedy nawet składano im propozycje matrymonialne ${ }^{39}$.

Adni hawaryli, szto jak papał charoszamu Niemcu - on żył jak czlen siemji i kuszał wmiestie za adnim stałom. A byli takiji słuczaji, szto im tuho było ${ }^{40}$.

No jej [siostrze - J.O.] papali oczeń charoszyje Niemcy. Wony tak jejo prosili, szto b ana nie ujeżdżała. (...) ani chatieli [ją - J.O.] astawit' i hawarat: „Nasz Hans (...) pryjdiot i na tiebie żenitsa, bo ty welmi dobra" ${ }^{41}$.

Wszakże, wedle udzielonych wywiadów, przykłady poprawnych relacji z niemieckimi gospodarzami nie wpłynęły realnie na ogólny obraz wyjazdów na roboty. Postawa robotników wynikała najprawdopodobniej z wykonywania ciężkiej pracy wśród obcej pod względem kulturowym ludności. Młode osoby paraliżował strach przed nieznanym społeczeństwem niemieckim, obawy potęgowała również bariera językowa, dlatego też młodzież wolała wykonywać te same, równie wyczerpujące zadania we własnych gospodarstwach, niż dobrowolnie pracować na rzecz Niemców-okupantów. Przytoczone przez badanych z Białorusi wspomnienia mogły mieć też na celu podkreślenie, iż choć u gospodarzy nie żyło się niektórym robotnikom najgorzej, pozostawali wierni sowieckiej ojczyźnie. Odwrotna postawa nie byłaby przecież zgodna z obowiązującymi na Białorusi ideałami.

Związane z wywózkami strach i niechęć przymusowych robotników, udzielały się również ludności pozostałej $\mathrm{w}$ rodzinnych stronach i tak też zostały przez nią zapamiętane. Ponadto, pamięć o robotach wśród białoruskiej społeczności wiejskiej zapisała się stosunkowo silnie, gdyż skutki wyjazdów do III Rzeszy odczuwano także po zakończeniu wojny, kiedy następował masowy powrót do domów wywiezionej młodzieży. Kobiety, które w efekcie gwałtów dokonywanych przez „wyzwalającą” Armię Czerwoną

\footnotetext{
37 K. Masalski, Księga pamięci prawosławnych mieszkańców Białostocczyzny, ofiar wydarzeń z lat 1939-1956, Białystok 2012, s. 323; Relacja Marii Wasiluk (Rzepiska) z 1 XI 2012...

38 J. Turonek, Białoruś pod okupacja niemieckq, Warszawa 1993, s. 111.

39 Relacja Lidii Ŝerbakovej (Kamieniuki) z 25 IX 2013 (zbiory autorki); Relacja Niny Dračuk...; Relacja Vladimira Šohaleviča (Kamieniuki) z 25 IX 2013 (zbiory autorki).

40 Tamże.

41 Relacja Lidii Ŝerbakovej...
} 
zachodziły w ciążę, w rodzinnych stronach okrywały hańbą swoich bliskich. Z zebranych wśród relacjonujących z Białorusi wywiadów wynika także, iż po powrocie $z$ robót unikano otwartego mówienia o odbytej pracy w Niemczech, będącego skutkiem obaw przed ewentualnymi represjami oraz przyszyciem łatki kolaboranta, a co za tym idzie, napiętnowaniem społecznym ${ }^{42}$. Podobne wspomnienia nie zostały przywołane przez narratorów z grupy polskiej, gdyż w Polsce przyznanie się do przymusowej pracy w Niemczech wzbudzało raczej współczucie, nie zaś podejrzenie o kolaborację.

Związane z wyjazdami na roboty zmniejszenie liczby rąk do pracy, rozdzielenie rodzin, strach przed "obcymi"-Niemcami czy napiętnowanie społeczne, w dużym stopniu wpłynęły na życie białoruskiej społeczności wiejskiej. Istotne znaczenie wymienionych kwestii dla przedstawicieli mieszkańców wsi pozwala stwierdzic, iż prowadzona przez stronę sowiecką agitacja antyniemiecka (zarówno z lat wojny, jak i okresu powojennego) nie musiała odegrać zasadniczej roli w kształtowaniu krytycznych postaw polskiej bądź białoruskiej grupy wobec robót przymusowych. Zagadnienie pracy w III Rzeszy zapamiętane zostało jednoznacznie negatywnie po obu stronach granicy.

Zdecydowanie najwięcej miejsca w zgromadzonych wspomnieniach członkowie polskiej i białoruskiej grupy poświęcili partyzantce sowieckiej i jej działalności, której aktywny rozwój na zamieszkiwanych przez relacjonujących obszarach następował od jesieni 1943 r. ${ }^{43}$ Czynnikiem determinującym znaczenie sowieckiego ruchu oporu zarówno w relacjach badanych z Polski, jak i Białorusi, były silne emocje towarzyszące pojawieniu się członków komunistycznego podziemia. Wiązały się one z przeprowadzanymi rekwizycjami z jednej i groźbą niemieckich represji za kontakt z partyzantką z drugiej strony. Ponadto, także zasięg oddziaływania funkcjonowania podziemia mógł zaważyć na szerokim omówieniu tego zagadnienia przez relacjonujących. Niemal w każdym wywiadzie znalazły się opowieści o zaopatrywaniu się przedstawicieli formacji leśnych w rodzinnym domu narratorów. Jeżeli w sąsiedztwie powstawały struktury partyzanckie, skutki ich działalności (w tym kary wymierzane przez okupanta stosującego metodę odpowiedzialności zbiorowej - ekspedycje karne czy akcje pacyfikacyjne ${ }^{44}$ ) wpływały na sytuację całej społeczności.

Choć relacjonujący bez trudu przywoływali wspomnienia związane z sowieckim ruchem oporu, niezwykle trudne okazało się określenie postawy

42 Tamże.

43 J. Turonek, dz. cyt., s. 119.

44 E. Mironowicz, Białoruś..., s. 198-200. 
badanych wobec członków partyzantki. Powiązania białoruskiej społeczności wiejskiej z przedstawicielami sowieckich formacji leśnych, które wynikały z tożsamego języka, kultury czy religii (wyłączając partyzantów narodowości żydowskiej), niosły za sobą określanie w wywiadach partyzantów, niezależnie od ewentualnych negatywnych przeżyć, mianem "swoich". To głównie ludność białoruska wsparła działalność sowieckiej partyzantki na byłych północno-wschodnich ziemiach II RP45. Niemniej jednak proste przypisanie relacjonującym-Białorusinom etykiety sympatyka komunistycznego ruchu oporu okazało się błędne. Zastosowania nie znalazło również oddzielenie grupy polskiej od białoruskiej jako w pełni kultywującej pamięć o partyzantach, wskutek prowadzonej przez państwo białoruskie polityki historycznej. $\mathrm{W}$ wywiadach nader często zarysowywał się ambiwalentny stosunek badanych, którzy z jednej strony utożsamiali się z podziemiem, z drugiej zaś podkreślali uciążliwość jego działalności. Zarówno przedstawiciele badanych z Polski, jak i Białorusi, przywoływali negatywne wspomnienia związane $\mathrm{z}$ kontaktami z sowieckim ruchem oporu. Tereny wiejskie stały się dla członków podziemia naturalnym obszarem pozyskiwania pożywienia, samogonu czy ubrań ${ }^{46}$. Zaopatrywanie się $\mathrm{w}$ podstawowe, umożliwiające przeżycie produkty, często przekraczało granice rzeczywistego zapotrzebowania i przybierało formę grabieży.

[Ludzie - J.O.] pomahali (ironicznie), partizany sami zabierut. Korowu zabierut, zarieżut ${ }^{47}$.

Na odnu nocz ne ma, na druhu znow prychodiat. Pomniu jak do chaty pryszli, a $u$ nas jak to cibuli winki, cieła radka była winkoł. Odin zaliez i usie winki zrywaje. A uże prosimo, kob chocz pokinuł nam na nasienie. To odnoho winka kinul, ne zabrał. Tody puszli do komory, a u komory szcze naszli mied - to zabrali ${ }^{48}$.

Lude im bojalisia dawati, wony sami hrabili. Brali, toje szto im i potrebne ${ }^{49}$.

Z drugiej zaś strony członkowie tych samych grup (polskiej i białoruskiej) wyrażali zrozumienie dla dokonywanych rekwizycji, gdyż partyzanci

żyli w liesi, to treba ż było im i odietisie i treba było i zimoju ubratisie ${ }^{50}$.

\footnotetext{
45 E. Mironowicz, Białorusini w Polsce..., s. 97.

46 E. Mironowicz, Sowieckie wojsko podziemne na Białorusi, „Białoruskie Zeszyty Historyczne” 2013, nr 39, s. 152.

47 Relacja Gerasima Dračuka...

48 Relacja Niny Moroz (Stare Berezowo) z 7 VI 2012...

49 Relacja Marii Wasiluk (Rzepiska) z 1 XI 2012...

50 Tamże.
} 
Niezależnie jednak od przywoływanych wspomnień, przekazanie części zbiorów rodziło problemy z wyżywieniem własnej rodziny i negatywnie odbijało się na życiu ludności wiejskiej. Ponadto, jak podkreślano w relacjach, każdy kontakt z sowieckim ruchem oporu groził srogimi represjami ze strony władz okupacyjnych, co potęgowało strach miejscowej społeczności.

(...) chto-nebud' skaże: „A w tebe byli partyzany" - wsio! Uże [Niemcy - J.O.] tuju siemju razstrylali ${ }^{51}$.

I takij był niebezpieczny czas. U deń straszno było Niemców, w nocze było straszno partyzanoł. I chto daść partyzanom chleba, (...) to uże joho ne zobaczysz, toho czołowieka ${ }^{52}$.

Częste odwoływanie się narratorów w wywiadach do własnych przeżyć daje podstawy do stwierdzenia, iż aspektem rzutującym na stosunek relacjonujących do podziemia były także indywidualne doświadczenia badanych, związane tak z partyzantką, jak i okupantem niemieckim. Krzywdy wyrządzone bliskim przez władze nazistowskie stawały się przyczyną silniejszego utożsamiania się z ruchem oporu, co przejawiało się $\mathrm{w}$ relacjach $\mathrm{w}$ przychylniejszym odnoszeniu się do jego przedstawicieli ${ }^{53}$.

Bat'ka [Niemcy - J.O.] zabrali, brata zabrali dwojirudnoho i tatinoho odnoho brata i druhoho brata i maminoho atca zabrali. (...) wsiech razstrylali. 11 czełowiek z dierewni naszoj razstrylali ${ }^{54}$.

Niemniej jednak negatywny obraz Niemców oraz wspomnienia związane z uciskiem miejscowej ludności będącego skutkiem kontaktu z partyzantką, wyraźniej zostały zarysowane $\mathrm{w}$ wywiadach udzielonych przez badanych z Białorusi. Powojenna propaganda komunistyczna za wschodnią granicą odegrała istotną rolę $\mathrm{w}$ kreowaniu obrazu partyzanta w pamięci grupy białoruskiej. Według oficjalnego stanowiska władz, sowiecki ruch oporu w czasie Wielkiej Wojny Ojczyźnianej miał niebagatelne znaczenie. Kultywując pamięć o członkach podziemia, pomijano będące ich udziałem niechlubne incydenty, jak np. rabunkowe metody przeprowadzania rekwizycji. Narratorzy, uczęszczając do powojennych szkół, które były wykorzystywane przez nowe władze do pożądanego kształtowania młodzieży ${ }^{55}$, uzyskiwali, a w związku

\footnotetext{
51 Relacja Lidii Ŝerbakovej...

52 Relacja Marii Wasiluk (Rzepiska) z 1 XI 2012...

53 Ibidem; Relacja Niny Dračuk...

54 Relacja Lidii Ŝerbakovej...

55 E. Mironowicz, Białoruś..., s. 250.
} 
z czym i przyswajali, wyłącznie państwową wersję wydarzeń. Sowiecki ruch oporu wysoką pozycję zajmuje także w pamięci politycznej współczesnego państwa białoruskiego, co przejawia się m.in. w znacznej liczbie wzniesionych na terenie Białorusi i otaczanych opieką pomników i monumentów, upamiętniających jego działalność56. Metody wykorzystywane w ideologii komunistycznej, podtrzymane i rozwinięte przez Aleksandra Łukaszenkę, w sposób oczywisty oddziałują na postrzeganie partyzantki przez obywateli. W związku z powyższym wpływ na ocenę działalności komunistycznych formacji leśnych przez badanych z Białorusi miał niewątpliwie również obecny system polityczny państwa białoruskiego. Jak zauważali sami relacjonujący, nie raz przyjmowali w swoich domach dziennikarzy, którym opowiadali o przeżytych tragediach i wskazywali miejsca rozstrzeliwań. Obowiązujący w państwie białoruskim kult pamięci o Wielkiej Wojnie Ojczyźnianej i kluczowej w niej roli sowieckiego podziemia, w sposób oczywisty ugruntował i wysunął na czoło wspomnienia o bezwzględności nazistów i ofiarności okupowanej ludności.

W przeciwieństwie do Białorusi, w Polsce większe niż propaganda komunistyczna znaczenie dla umocowania się pamięci o sowieckim podziemiu wśród białoruskiej społeczności wiejskiej z pewnością miały przywoływane już emocje i wpływ działalności formacji leśnych na życie codzienne. W przypadku powojennego państwa polskiego poruszanie zagadnienia sowieckiego ruchu oporu nie było tak popularne ze względu na problem zwalczanej przez władze komunistyczne polskiej partyzantki. Należy jednak podkreślić, iż członkowie badanej grupy we wspomnieniach wyraźnie oddzielali podziemie sowieckie od polskiego, najczęściej określanego przez nich jako po prostu "AK”, nie zaś „partyzantka”. W szeregi podziemia, niezależnie od pobudek, wstępowali „swoji lude" 57 , z kolei Armia Krajowa stanowiła dla narratorów obcą formację ${ }^{58}$.

Wywiady zebrane wśród białoruskiej społeczności wiejskiej dowodzą, iż obraz okupacji niemieckiej widzianej oczami narratorów ogranicza się do kilku wydarzeń: kontyngentów, wywózek na roboty przymusowe i działalności sowieckiej partyzantki. Relacjonujący we wspomnieniach nie wykazywali

56 W. Śleszyński, dz. cyt., s. 104.

57 Relacja Marii Mińko (Rzepiska) z 6 VI 2012 (zbiory autorki).

58 Obcość polskiej partyzantki dodatkowo wzmogła pamięć o powojennych działaniach oddziału dowodzonego przez kpt. Romualda Rajsa „Burego" (zob. np.: W. Choruży, Spalenie wsi Zanie przez oddziat PAS NZW kpt. Romualda Rajsa "Burego", "Białoruskie Zeszyty Historyczne" 2002, nr 18; O. Łatyszonek, E. Mironowicz, Historia Białorusi od połowy XVIII do końca XX wieku, Białystok 2002, s. 244-245. 
posiadania szerokiej wiedzy dotyczącej lat 1941-1944, skupili się natomiast na kwestiach najlepiej przez nich zapamiętanych. Z perspektywy prowadzonego badania niewątpliwie podnosi to wartość relacji, gdyż świadczy o ich autentyczności. Zgromadzone wspomnienia pozwalają także stwierdzić, iż różnica między polską a białoruską grupą nie polegała na wykreowaniu rozbieżnego obrazu przeszłości. W żadnym z poruszanych przez badanych zagadnień (kontyngenty, wywózki czy sowieckie podziemie) nie można dokonać radykalnego podziału na stanowisko narratorów z Polski i Białorusi. Zarysowana różnica wynikała raczej z odmiennych czynników, które wzmacniały konkretną pamięć.

Przeciwko historii mówionej i samym źródłom ustnym są wysuwane liczne zarzuty, m.in. brak wiarygodności, reprezentatywności oraz subiektywizm $^{59}$. Należy jednak pamiętać, iż celem relacji nie jest zastąpienie, czy też podważenie źródeł pisanych. Stanowią natomiast wartość, gdy nie można dotrzeć do innych materiałów lub ich liczba jest ograniczona, jak w przypadku badań mających na celu przedstawienie II wojny światowej z perspektywy białoruskiej społeczności wiejskiej. Zasadnym okazuje się też stwierdzenie, iż dają wówczas żywy ogląd minionych wydarzeń. Powyżej starano się także wykazać możliwości wynikające z wykorzystania wywiadów w badaniach polegających na analizie pamięci danej grupy. Nie tylko ukazują, co i w jaki sposób zostało zapamiętane, ale pozwalają na zastanowienie się nad przyczynami utartych wspomnień, włączając $w$ to również kwestię państwowej polityki historycznej. $\mathrm{W}$ takim przypadku subiektywizm relacji staje się przedmiotem badań i jednocześnie ich zaletą.

\title{
The importance of oral history as a research method exemplified by the Belarusian rural community of the Polish-Belarusian Borderland
}

\begin{abstract}
Oral history is becoming a more and more popular research method involving collecting and critical analyzing of interviews made with the witnesses of history. Basic advantages of oral history and the accounts themselves distinguishing them from other historical sources undoubtedly include: a direct contact with a narrator, a possibility of verifying reliability or completing written sources, and determining motifs or atmosphere of past events. Moreover, oral history research allow to make an attempt at
\end{abstract}

\footnotetext{
59 T. Królik, dz. cyt.
} 
analyzing memory of a specific group such as, for example, the picture of German occupation of World War II as seen by the Belarusian rural community of the Polish-Belarusian Borderland.

Interviews collected from Polish and Belarusian narrators revealed that both the outbreak of the German-Soviet war as well as the time of occupation itself have been strongly preserved in the respondents' memories. The accounts of Polish and Belarusian groups mostly focused on the issue of contingents, deportations for forced labor to the Third Reich and Soviet guerillas operations. The respondents' individual experiences with Nazi authorities have certainly influenced memorizing specific events by them as well as the manner of remembering them. What is more, the respondents' attitude to German soldiers who, due to their distinct language, culture and religion became "foreign" to local people, played an important role too. On the other hand, the picture of occupation was also influenced by external factors such as widely understood historical policy and other postwar experiences of the narrators.

The research of the respondents from Poland and Belarus revealed that the period of German occupation was not remembered differently by the representatives of both groups. Introducing a radical division into the opinions on any issue raised by the respondents (contingents, deportations or guerillas) held by the Polish group and the Belarusian one turned out to be impossible. Nevertheless, factors shaping their memory of the events in 1941-1944 were different.

Key words: oral history, Belarusian rural community, the Polish-Belarusian Borderland, World War II, German occupation

\section{Значение устной истории как исследовательского метода на примере белорусской деревенской общественности приграничной польско-белорусской зоны}

\section{Абстракт}

Устная история становится все более популярным исследовательским методом, основанным на составлении и критическом анализе опросов, проведенных среди очевидцев исторических событий. Основными преимушествами oral history и самих взаимоотношений, выделяюшихся на фоне других исторических источников, несомненно являются: непосредственный контакт с рассказчиком, возможность верификации надежности или дополнения письменных источников, определение мотивов или атмосферы минувших событий. Более того, исследования oral history дают возможность проанализировать воспоминания данной группы, например, при изучении немецкой оккупации во время II Мировой войны, свидетелями которой была белорусская деревенская общественность приграничной польско-белорусской зоны. 
На основании рассказов очевидцев из Польши и Белоруссии оказалось, что начало немецко-советской войны, как и период оккупации, оставили яркий след в их памяти. В повествованиях польской и белорусской группы больше всего внимания уделялось вопросу контингентов, вывозке на принудительные работы в III Рейх и советскому партизанскому движению. На воспоминания очевидцев, описывающих события, несомненно повлиял индивидуальный опыт каждого из них, касающийся времени нацистской власти. Важную роль также сыграло отношение очевидцев к немецким солдатам, которые из-за иностранного языка, культуры и религии становились для населения «чужими». С мругой стороны, на образ оккупации влияли также внешние условия, такие как, широко понимаемая историческая политика и другие послевоенные, пережитые рассказчиками, ситуации.

На основании исследуемого материала, полученного от очевидцев из Польши и Белоруссии, оказалось, что период немецкой оккупации оставил похожий след в памяти представителей обоих групп. Оказалось невозможным радикально разделить информацию, полученную от польской и белорусской групп, информацию о контингентах, вывозках и партизанском движении. В свою очередь, разными оказались факторы, повлиявшие на воспоминания о произошедшем в 19411944 годах.

Ключевые слова: устная история, белорусская деревенская общественность, польско-белорусская приграничная зона, II Мировая война, немецкая оккупация

\section{Bibliografia}

\section{Relacje}

Relacja Andrzeja Zawackiego (Koryciski) z 31 III 2013 (zbiory autorki).

Relacja Anny Owłasiuk (Stare Berezowo) z 11 XI 2012 (zbiory autorki).

Relacja Gerasima Dračuka (Rożkówka) z 11 I 2014 (zbiory autorki).

Relacja Józefa Moroza (Stare Berezowo) z 26 VIII 2014 (zbiory autorki).

Relacja Józefa Moroza (Stare Berezowo) z 7 VI 2012 (zbiory autorki).

Relacja Lidii Ŝerbakovej (Kamieniuki) z 25 IX 2013 (zbiory autorki).

Relacja Marii Mińko (Rzepiska) z 6 VI 2012 (zbiory autorki).

Relacja Marii Wasiluk (Rzepiska) z 1 XI 2012 (zbiory autorki).

Relacja Marii Wasiluk (Rzepiska) z 17 IX 2013 (zbiory autorki).

Relacja Mihaila Mel'ničuka (Podbielskie Ogrodniki) z 12 X 2013 (zbiory autorki).

Relacja Mikołaja Owłasiuka (Stare Berezowo) z 4 VII 2012 (zbiory autorki).

Relacja Niny Dračuk (Rożkówka) z 12 X 2013 (zbiory autorki).

Relacja Niny Moroz (Stare Berezowo) z 7 VI 2012 (zbiory autorki).

Relacja Vadima Sinâka (Kamieniuki) z 25 IX 2013 (zbiory autorki).

Relacja Vladimira Šohaleviča (Kamieniuki) z 25 IX 2013 (zbiory autorki). 


\section{Opracowania}

Boćkowski D., Na zawsze razem. Białostocczyzna i Łomżyńskie w polityce radzieckiej w czasie II wojny światowej (IX 1939-VIII 1944), Warszawa 2005.

Choruży W., Spalenie wsi Zanie przez oddział PAS NZW kpt. Romualda Rajsa "Burego", „Białoruskie Zeszyty Historyczne” 2002, nr 18.

Filipkowski P., Historia mówiona i wojna, http://biblioteka.teatrnn.pl/dlibra/Content/ 9618/Historia_mowiona_i_wojna.pdf [04.08.2016].

Kałwa D., Historia mówiona w krajach postkomunistycznych. Rekonesans, „Kultura i Historia" 2010, nr 18, http://www.kulturaihistoria.umcs.lublin.pl/archives/1887 [04.08.2016].

Kersten K., Relacje jako typ źródła historycznego, [w:] Pamiętnik X Powszechnego Zjazdu Historyków Polskich w Lublinie, 17-21 września 1968 r. Referaty plenarne. Sekcje VII-XI, Warszawa 1968.

Królik T., Wprowadzenie do oral history, http://homepage.univie.ac.at/philipp.ther/ breslau/html/wprowadzenie.html [04.08.2016].

Kurkowska-Budzan M., Historia zwykłych ludzi. Wspótczesna angielska historiografia dziejów społecznych, Kraków 2003.

Lewandowska I., Historycy wobec metody oral history. Przeglad polskiej literatury naukowej, [w:] Historia. Archiwistyka. Praca naukowa. Prace dedykowane Profesorowi Bohdanowi Ryszewskiemu, red. M. Świgoń, Olsztyn 2009.

Lewandowska I., Oral history we wspótczesnej Polsce - badania, projekty, stowarzyszenia, „Wrocławski Rocznik Historii Mówionej" 2011, t. 1.

Łatyszonek O., Mironowicz E., Historia Białorusi od połowy XVIII do końca XX wieku, Białystok 2002.

Masalski K., Księga pamięci prawosławnych mieszkańców Białostocczyzny, ofiar wydarzeń z lat 1939-1956, Białystok 2012.

Mironowicz E., Białorusini w Polsce 1944-1949, Warszawa 1993.

Mironowicz E., Prowincja i stolica - okupacyjna codzienność na Białorusi, „Białoruskie Zeszyty Historyczne" 2013, nr 40.

Mironowicz E., Rok 1941 na Białorusi, „Białoruskie Zeszyty Historyczne” 2011, nr 35.

Mironowicz E., Sowieckie wojsko podziemne na Białorusi, „Białoruskie Zeszyty Historyczne" 2013, nr 39.

Mironowicz E., Zmiany struktury etnicznej na Białorusi w okresie okupacji niemieckiej (1941-1944), „Białoruskie Zeszyty Historyczne” 2004, nr 21.

Turonek J., Białoruśs pod okupacja niemiecka, Warszawa 1993.

Śleszyński W., Kresy Wschodnie czyli Białoruś Zachodnia. Historia, wspótczesność, pamięć, Łomianki 2013.

Justyna Owłasiuk, mgr stosunków międzynarodowych, pracuje w Bibliotece Wydziału Historyczno-Socjologicznego Uniwersytetu w Białymstoku.

e-mail: owlasiukjustyna@wp.pl 